\title{
Influence of Sociocultural Factors and Acceptance of Creationism in the Comprehension of Evolutionary Biology in Freshman Brazilian Students
}

\author{
Pierre R. Penteado $\cdot$ Karine F. Kavalco $\cdot$ Rubens Pazza
}

Published online: 18 October 2012

(C) Springer Science+Business Media New York 2012

\begin{abstract}
The creationist movements in Brazil, although considered weak, are on the increase. The Brazilian legislation neither imposes any objection in teaching evolution nor obliges the teaching of creationism as an alternative to evolution in science classes. Furthermore, it allows the optional teaching of religion at schools. The aim of the present study was to evaluate the knowledge regarding biological evolution in freshman students from a Brazilian university. Such knowledge was related to sociocultural factors such as their parental education level, the type of high school the student graduated from (private or public school), their philosophical/religious position as well as the acceptance of creationism as an alternative to evolution. Among those factors, the latter two showed significant differences, in which the higher averages belonged both to the atheistic students and to those who do not accept creationism as an alternative to evolution.
\end{abstract}

Keywords Science education - Teaching evolution . Intelligent Design $\cdot$ Religious position

\section{Introduction}

There has been a historical debate in North American courts regarding the teaching of evolution in science classes and the teaching of creationism as an alternative to evolution. Since creationism may be considered neither an alternative to evolution nor a subject taught in science classes (Scott 1997), not a single state currently uses its content standards

P. R. Penteado · K. F. Kavalco $\cdot$ R. Pazza $(\bowtie)$

Universidade Federal de Viçosa-UFV, Campus de Rio Paranaíba, Laboratório de Genética Ecológica e Evolutiva,

Rodovia BR 354, km 310, Campus Universitário, PO Box 22, Rio

Paranaíba, MG, Brazil 38810-000

e-mail: rpazza@ufv.br to explicitly promote creationism (Berkman et al. 2008). On the other hand, a wide survey carried out by Lerner (2000) showed that one third of the U.S. offers weak evolutionary content in the science curriculum. A consequence of this disparity is seen in opinion polls that reveal less than $50 \%$ of Americans accept Darwin's theory of evolution by natural selection (Miller et al. 2006).

One strategy for creationists is an attempt to transform creationism into a science using contributions from scientists as authoritative arguments in order to create "scientific creationism." To accomplish this, they must adopt both the scientific method and the principle of parsimony. The most recent attempt to transform creationism into science is based on the theological argument formerly offered by William Paley (1803), stating that God is proved by His creation. Paley wrote that if a pocket watch was found on a forest, we would certainly assume that it had been made by a watchmaker. However, that argument was not new then and had already been strongly criticized by Hume (1779). In this argument, called Intelligent Design (ID), creationist scientists support the idea that the complexity of life found on Earth can only be explained by the intervention of an intelligent designer. Most ID supporters argue this is not a religious formulation; rather, it is scientific, thus being enough to work as an alternative to evolution. Such an idea has been acceptable to religious people (chiefly evangelical Protestants) since the model of an "intelligent designer" would fit perfectly with the image of their deity, giving a scientific sense to creationism. Nevertheless, such a formulation is neither recognized as science academically nor by the Catholic Church. The latter asserts that teaching ID connected with evolutionary theory only generates confusion (Winfield 2005; Associated Press 2006). Not being recognized as a science, creationists found a way to teach it (neo-creationism) in philosophy classes instead (Barbassa 2006). 
Catholics represent the largest religious group in Brazil, although the number of adherents has been decreasing over the last years (Almeida and Montero 2001). Census and opinion polls performed from 1980 to 2007 reveal a constant drop in the number of Catholics (89.2$64 \%$ ) and an increase of evangelicals (6.6-22\%) and the non-religious or atheist (1.6-7\%). Furthermore, a significant number of Catholics practice some sort of religious syncretism, mainly with esoteric and African creeds, besides a large number of people who consider themselves "non-practitioners" participating in some rituals, such as a wedding or baptism, but not attending church regularly or evincing special devotion to a saint, for example (Almeida and Montero 2001). Among Evangelists, there has been a remarkable expansion of Pentecostal and Neopentecostal groups, with an increase of nearly $8.9 \%$ a year, whereas the traditional Evangelical groups are growing by about 5.2\% per year (Mariano 2004). Census data (IBGE 2000) demonstrated that Pentecostal followers mostly comprise people with incomes lower than the national average, while most traditional Protestants earn more than the national average.

The standard age of freshmen at public universities in Brazil is about 18 years old. At this age, the proportion of Catholics (74\%), Evangelists (14\%), Spiritists (1\%), and non-religious $(8.6 \%)$ reflects the overall data of the last census survey (IBGE 2000), and it is close to the values observed in the present study (Table 1).

Table 1 Means and variance on evaluation of evolutionary biology concepts among students, according to their options in the sociocultural questions

\begin{tabular}{llll}
\hline Questions/alternatives & Mean & Variance & $\%$ \\
\hline $\begin{array}{l}\text { Creationism should be taught in the science classes as an alternative to } \\
\text { the evolutionary theory? }\end{array}$ & 4.62 & 1.99 & 73 \\
Yes & 5.46 & 3.19 & 27 \\
No & & & \\
Parental education level & 4.75 & 2.66 & 38 \\
Fundamental level & 5 & 2.36 & 38 \\
High School & 4.86 & 2.48 & 24 \\
College & 4.8 & 2.55 & 71 \\
Student's high school graduation & institution & & \\
Public & 5.22 & 2.12 & 29 \\
Private & & & \\
Philosophic/religious position & 4.72 & 2.33 & 78 \\
Catholic & 4.86 & 2.13 & 9 \\
Evangelic & 6.17 & 2.57 & 3 \\
Spiritist & 6.5 & 3.18 & 5 \\
Atheist & 4.9 & 1.90 & 5 \\
Others & 4.86 & 2.53 & \\
Total & & & \\
\hline
\end{tabular}

Although the creationist movement is still modest in Brazil when compared to that in the U.S., the Brazilian Creationist Society was funded in 1972 and has organized several events, periodicals, books, and videos (www.scb.org.br). Moreover, one of the largest Brazilian TV broadcasters, Record, is owned by the Evangelistic Universal Church of the Reign of the God, while other institutions, including the Catholic Church, own small broadcasting stations.

In Brazil, there is no legal prohibition to religious teaching at schools, although the freedom of speech makes them facultative. According to the Brazilian Constitution, the state is non-religious. However, not long ago, the teaching of creationism, relying upon the Bible, in science classes was raised by an Evangelical Protestant governor in the state of Rio de Janeiro as an alternative to evolution (Gazir 2004), and the number of adherents favorable to this proposal has increased significantly ever since.

The aim of the present study was to evaluate the influence of some sociocultural features upon learning about and understanding biological evolution in freshman university students. Furthermore, their acceptance or not of teaching creationism in science classes as an alternative to evolution was also ascertained.

\section{Material and Methods}

In the present study, 231 freshman students from Universidade Estadual do Centro-Oeste do Paraná (Brazil) were interviewed. They were attending first-year classes both in biological sciences (morning and evening schedule), exact sciences (agronomy, physics, chemistry, and math), and human sciences (history, geography, and pedagogy). The research was done using a questionnaire composed of ten questions about evolution, comprising the chief issues of evolutionary theory in distinct levels of difficulty. Furthermore, four sociocultural questions related to the acceptance or rejection of the teaching of creationism in science classes as an alternative to evolution, parental education level, the type of high school institution from which the student graduated (public or private school), and religious or philosophical position were also included and evaluated. The questionnaire about evolution used for the calculated means is according to Pazza et al. (2010), and the sociocultural questions are summarized in Table 1.

The research results were tabulated and analyzed, obtaining both the descriptive statistics and the demonstrative graphs. The data were submitted to variance analysis and a comparative average test using Tukey and Mann-Whitney test, as well as the nonparametric Kruskal-Wallis test, using the software PAST v1.67b (Hammer et al. 2001). 


\section{Results}

The total average score obtained by the students interviewed was 4.86. The data shown in Table 1 summarize the average, variance, and percentage of interviewed students according to each alternative regarding the sociocultural questions.

Most of the agronomy and geography students do not support the teaching of creationism in science classes as an alternative to the evolutionary theory, while in the other courses, the majority was favorable to creationism (Fig. 1). Among them, the pedagogy course showed the highest level of approval. The level of parental education varied considerably, but most parents were college graduates among agronomy and chemistry students (Fig. 2a). The majority of the students had graduated from public high schools, mainly those majoring in pedagogy (Fig. 2b). The pedagogy course also showed the highest percentage of Catholics, who represent the majority among all selected courses (Fig. 2c).

The variance analysis related to the acceptance of creationism $(F=14.55, p=0.0001769$, Mann-Whitney $p=$ $0.000672)$, and religious/philosophical position $(F=4.912$, $p=0.000819$, Kruskal-Wallis $p=0.0067$ ) showed significant differences. The pairwise analysis concerning the religious/ philosophical position may be observed in Table 2. On the other hand, there were no significant differences related to the level of parental education $(F=0.5634, p=0.5701$, Kruskal-Wallis $p=0.511$ ) and type of high school (private or public) $(F=2.113, p=0.1475$ Mann-Whitney $p=0.2293)$.

\section{Discussion}

According to Rutledge and Mitchell (2002), either the acceptance or rejection of evolutionary theory as a valid scientific explanation may influence the students' comprehension about this powerful idea. On the other hand, an agreement between teachers and students regarding evolutionary ideas about this issue is also necessary.

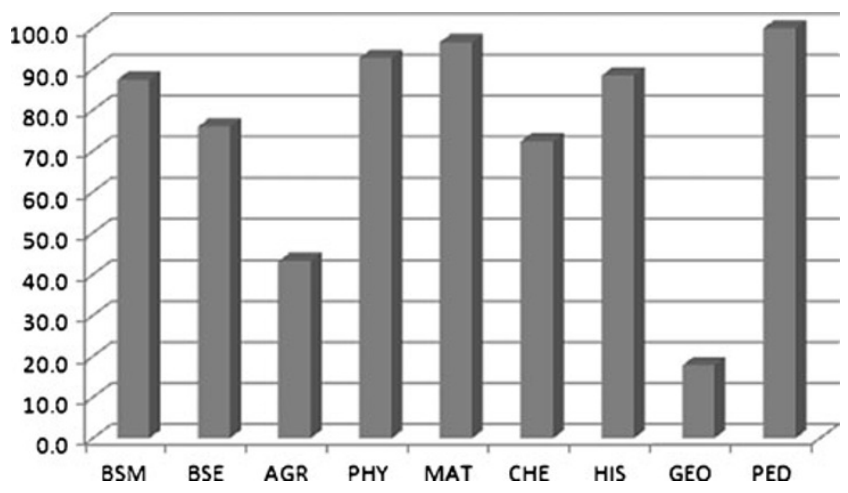

Fig. 1 Bar graph showing the students' perception on the teaching of creationism in science classes as an alternative to the evolutionary theory

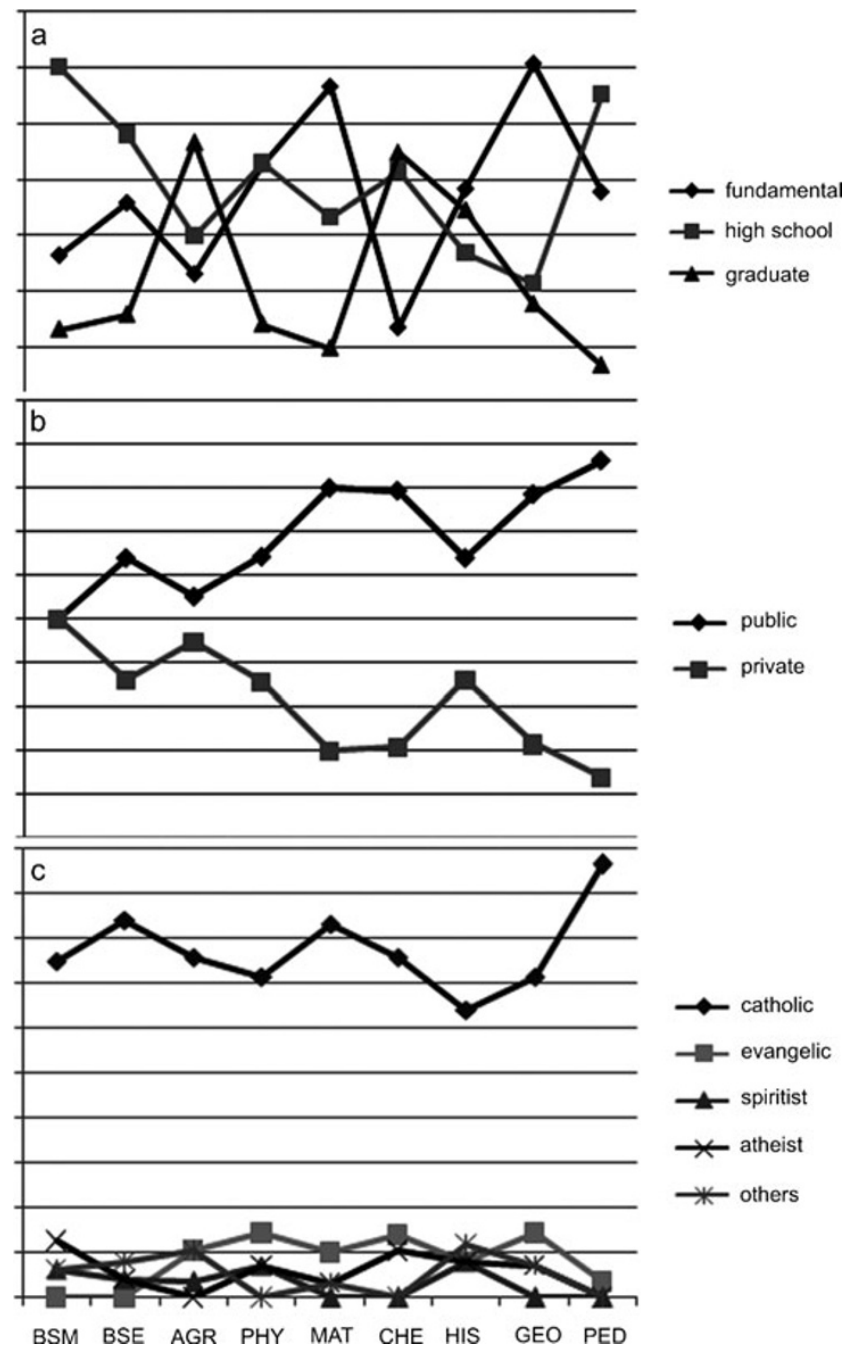

Fig. 2 a Most parents were college graduates among agronomy and chemistry students. b The majority of the students had graduated from public high schools, mainly those majoring in pedagogy. $\mathbf{c}$ The pedagogy course also showed the highest percentage of Catholics, who represent the majority among all selected courses

Furthermore, Lombrozo et al. (2008) observed that the acceptance of evolution by college students is positively correlated to their understanding of the scientific principles. So teaching of evolution is a hard task when teachers have their own convictions. Thus, some religions, highly opposed to evolutionary theory and its supporting scientific evidence, can threaten comprehension of biological evolution by the faithful. Furthermore, distinct Christian groups differ on the level of acceptance of evolutionary theory, ranging from the Young Earth Bible literalists (who do not accept the Earth's geological dating, given that the sum of the age of Biblical patriarchs indicates an origin for human beings and the universe, as created by God, of less than 6,000 years ago), the Old Earth creationists (who accept the age of the Earth and the universe among other 
Table 2 Tukey/Mann-Whitney comparative analysis of means according to religious/philosophic choices

\begin{tabular}{llllll}
\hline & Catholics & Evangelics & Spiritists & Atheists & Other \\
\hline Catholics & & 0.785 & 0.04714 & 0.001296 & 0.5082 \\
Evangelics & 0.9994 & & 0.09648 & 0.01351 & 0.7222 \\
Spiritists & 0.1136 & 0.1881 & & 0.5741 & 0.2234 \\
Atheists & 0.02557 & 0.0494 & 0.9814 & & 0.02623 \\
Other & 0.9975 & 1 & 0.2292 & 0.06448 & \\
\hline
\end{tabular}

scientific evidence), and other types of essentially Christian creationism to the neo-creationist movement of ID (Scott 1997).

In the present study, it is possible to observe that most of the interviewed students are favorable to the teaching of creationism in science classes as an alternative to evolution. On the other hand, it also shows that the average of students opposed to creationism is significantly higher (MannWhitney $p=0.000672$ ). This result is likely due to the lack of knowledge of scientific method by the students, which may be a reflex response both to the teachers' understanding and acceptance of evolution (Rugledge and Warden 2000) and to their own beliefs (Sinclair et al. 1997; Miller et al. 2006; Chinsamy and Plagányi 2008). Rutledge and Mitchell (2002) suggest that the teachers need to be aware of how scientific knowledge is produced. Basic notions about epistemology and the philosophy of science will enable them to distinguish that creationism does not belong in a science class. Moore (2008) points out that most U.S. students would like to have Christian creationism in their biology classes, and that creationism is taught by the teachers as a valid scientific theory, not a philosophical or religious idea. Unfortunately, it is difficult to relate such students' attitude to their misunderstanding of the scientific method or their own conceptions and beliefs.

On the other hand, if we accept creationism teaching as an alternative to evolution in science classes, a question must be raised: what type of creationism must be taught? Several peoples have their creation myths: (Sproul 1979; Leeming and Leeming 1994) the Jewish people wrote down their myths in the Jewish Torah and the Christian Bible. What makes one truer than the other? Perhaps the creationism that should be taught in Brazil is the most diffused one, i.e., the creationism based on the Christian Bible. Nevertheless, there is no agreement among Christian creationists and, hence, it is not possible to determine what type of creationism must be taughtYoung Earth, Old Earth, or Intelligent Design.

Interestingly, the highest rate of students who accept the teaching of creationism belongs to the biological sciences course, which obtained a significantly higher average than other courses (Pazza et al., 2010), which could be explained by the students' religious choices, most of them Catholics.
Some of these students will eventually become biology teachers, and if the perceptions of the teaching/learning process in universities are not to be changed, they might teach equivocated interpretations to their students. Berkman et al. (2008) observed that teachers accepted that human beings were created by God as they are today in a period shorter than 10,000 years (Young Earth creationism), and they dedicated 35\% less time in teaching evolution during biology classes than in other courses. These authors have also verified that the teachers who attended more class hours of evolution during their majoring courses demanded more time for evolution teaching in their biology classes, and well-prepared teachers used up to $60 \%$ more time in teaching evolution than the others. This fact suggests that teachers' preparation is the key to providing students a complete and qualified view of the evolutionary process. In Germany, $8 \%$ of the biology students planning to teach believe in Young Earth Creationism, a result related to the German study model, where the Christian religion is taught very early at schools while science classes are initiated later, leaving a short time to evolution teaching in high school (Kutschera 2008).

Tidon and Lewontin (2004) showed that one of the greatest problems in teaching evolution is, unfortunately, related to the teachers' background. Although these teachers assure that it is easy to teach Darwinian and Lamarckian theories about how living beings change, other questionnaire answers show a clear agreement with the Lamarckian hypothesis (Tidon and Lewontin 2004). If teachers don't know evolution, it is expected that they cannot teach evolutionary biology, and the background on evolution of entering college students will be poor. Besides, teaching of evolution involves more than teachers' background issues. One of the problems the teachers must face while teaching evolution relates to the textbooks, which almost always present key contents both in a superficial way and with few exercises (Aleixandre 1994). In Brazil, the textbooks used in secondary schools have significantly improved their quality (Bizzo 2000), but a thorough evaluation of specific contents is still scarce.

The percentage of interviewed students concerning their religious/philosophical position is in accordance with the national average (IBGE 2000), showing that in Brazil, most of the population pratice Judeo-Christian or related religions, Catholicism being most widespread. Scott (1997) says that a theistic evolution approach (in which evolution is accepted, but all was created and guided through divine intervention) is the official position of Catholic Church, and also taught in some Protestant seminaries. This position was reiterated by Pope John Paul II in 1996. Such dualism could be the explanation for the results found in biological science students. Kutschera (2008) observed that anti-evolutionary movements are stronger in Western Germany, where Christian schools teach their religions when compared to 
the Eastern Germany (Communist) where a solid scientific education was a part of their ideology. In the U.S., $47 \%$ of interviewed teachers believe that God interferes in the evolutionary process (Berkman et al. 2008), a typical ID view.

As for the religious or philosophical position of the interviewed students, it is possible to observe a significant difference, where the highest average was obtained by atheists/agnostics, followed by adherents of spiritism. Similar to our findings, studies involving zoology and other students showed that their religious convictions interfered either in the ability to visualize the evolutionary evidence or even accept it (Lawson and Weser 1990; Sinclair et al. 1997; Sinclair and Pendarvis 1998; Meglhioratti et al. 2005). Although most objections to biological evolution come from fundamentalists, we observed that even among Catholics, their religious convictions interfered in the comprehension of both evolutionary evidence and the process of evolution itself. Additionally, there is evidence that strong religious views could make it harder to change the mindset regarding evolution (Miller et al. 2006; Chinsamy and Plagányi 2008).

The conflict between teachers' own convictions and preestablished concepts about biological evolution raises difficulties in the teaching-learning process of such an important field of knowledge. Although different religions show different ways of accepting evolution (Scott 1997), the materialistic position about the evolutionary processes assumed by several scientists, such as Richard Dawkins (1987) and William Provine (1988), reinforce the thought of the literalists, who state that nobody can be a Christian and an evolutionist at the same time.

In the face of this dilemma, a constructivist teaching approach that relates evolution to the reality of the students seems the most effective path to follow (Jensen and Finley 1996; Alters and Nelson 2002; Zuzovsky 1994), coupled with incentives students debate, creation of concept maps, and greater historical richness in explanations (Alters and Nelson 2002). Besides these basic recommendations, it is important to qualify teachers, not only regarding their teaching strategies but also the curriculum content. Obviously, each teacher needs to adapt his methodology to the teaching conditions of the institution. Nonetheless, the development of a more productive methodology is useless when the teachers themselves oppose evolution due to their personal convictions (Meglhioratti et al. 2005), which reflects on their lack of background (Rugledge and Warden 2000; Tidon and Lewontin 2004). If the teachers themselves lack either the background or confidence in the subject taught, the teaching process as a whole is jeopardized.

To a lesser degree, the average of students from private schools was significantly higher than the average of those from public schools. Nonetheless, there were no significant differences in the students' average relative to parental education.
Considering the importance of evolution to the study of both biodiversity and to issues such as health and agriculture, it is mandatory to lessen the effects of sociocultural traits on the learning process. Thus, teachers, chiefly at public schools, need to be better prepared and encouraged to manage working on the content under a constructivist focus and in an attractive way to the students. Other resources apart from those offered by the textbooks must be available to the students as well, such as internet access for research, scientific books and magazines, among other tools. Most importantly, the teacher should be acquainted with the science and with how it is produced (Rutledge and Mitchell 2002) in order to minimize the harmful effects of preconceived ideas based on their own (and students' as well) convictions about evolutionary issues.

Acknowledgments The authors thank those who coordinated the courses that took part in this research for the opportunity granted.

\section{References}

Aleixandre MPJ. Teaching evolution and natural selection: a look at textbooks and teachers. J Res Sci Teach. 1999;31(5):519-35. 1994. doi: tea.3660310507.

Almeida R, Montero P. Trânsito religioso no Brasil. São Paulo em Perspectiva. 2001;15(3):92-100.

Alters BJ, Nelson CE. Perspective: teaching evolution in higher education. Evolution. 2002;56:1891-901.

Associated Press. Vatican paper hits 'Intelligent Design'. CBS News 01/18. 2006; http://www.cbsnews.com. Accessed 15 Dec 2011.

Barbassa J. California School System Calls Off Class on 'Intelligent Design'. Washington Post (Associated Press). 2006; http:// www.washingtonpost.com. Accessed 13 Dec 2011.

Berkman MB, Pacheco JS, Plutzer E. Evolution and creationism in America's classrooms: a national portrait. PLoS Biology. 2008;6 (5): 124

Bizzo NMV. Falhas no ensino de ciências. Ciência Hoje. 2000;159:26-31.

Chinsamy A, Plagányi É. Accepting evolution. Evolution. 2008;62 (1):248-54.

Dawkins R. The blind Watchmaker. New York: Norton; 1987.

Gazir A. Escolas do Rio vão ensinar criacionismo. Folha de São Paulo. 2004; http://www1.folha.uol.com.br/folha/ciencia/ult306u11748.shtml. Acessed 21 Jan 2012.

Hammer O, Harper DAT, Ryan PD. PAST: Palaeontological statistics software package for education and data analysis. Palaeontol Electron. 2001;4(1):9pp.

Hume D. Dialogues concerning natural religion. Richard Popkin (ed). Indianapolis: Hackett; 1779.

IBGE (Instituto Brasileiro de Geografia e Estatística) Pesquisa nacional por amostra de domicílio. Senso demográfico 2000. Instituto Brasileiro de Geografia e Estatística. 2000; www.edeus.org/port/ IBGEBR.htm. Accessed 17 Jan 2009.

Jensen MS, Finley FN. Changes in students' understanding of evolution resulting from different curricular and instructional strategies. J Res Sci Teach. 1996;33(8):879-900.

Kutschera U. Creationism in Germany and its possible causes. Evo Edu Outreach. 2008;1:84-6. 
Lawson AE, Weser J. The rejection of nonscientific beliefs about life: effects of instruction and reasoning skills. J Res Sci Teach. 1990;27:589-606.

Leeming DA, Leeming MA. A dictionary of creation myths. Oxford: Oxford University Press; 1994.

Lerner LS. Good and bad science in US schools. Nature; 2000;407:287290.

Lombrozo T, Thanukos A, Weisberg M. The importance of understanding the nature of science for accepting evolution. Evo Edu Outreach. 2008;1:290-8.

Mariano R. Expansão Pentecostal no Brasil: o caso da Igreja Universal. Estudos Avançados. 2004;8(52):121-38.

Meglhioratti FA, Bortolozzi J, Caldeira AMA. História da biologia: aproximações as possíveis entre as categorias históricas e as concepções sobre ciência e evolução apresentadas pelos professores de biologia. In: Caldeira AMA, Caluzi JJ, editors. Filosofia e história da ciência - contribuições para o ensino de ciência. Ribeirão Preto, SP: Kayrós Editora; 2005. p. 11-28.

Miller JD, Scott EC, Okamoto S. Public acceptance of evolution. Science. 2006;311:34

Moore R. Creationism in the biology classroom: what do teachers teach \& how do they teach it? Am Biol Teach. 2008;70(2):79-84.

Paley W. Natural theology: or, evidences of the existence and attributes of the deity, collected from the appearances of nature. London: Faulder; 1803.

Pazza R, Penteado PR, Kavalco KF. Misconceptions about evolution in brazilian freshmen students. Evo Edu Outreach. 2010;3:107-113.
Provine W. Scientists, face it! Science and religion are incompatible. Scientist. 1988;2:10.

Rugledge ML, Warden M. Evolutionary theory, the nature of science and high school biology teachers: a critical relationships. Am Biol Teach. 2000;62:23-31.

Rutledge ML, Mitchell MA. High school biology teachers' knowledge structure, acceptance and teaching of evolution. Am Biol Teach. 2002;64(1):21-8.

Scott EC. Antievolution and creationism in the United States. Annu Rev Anthropol. 1997;26:263-89.

Sinclair A, Pendarvis MP. Evolution versus conservative religious beliefs: can biology instructors assist students with their dilemma? J Coll Sci Teach. 1998;27:167-70.

Sinclair A, Pendarvis MP, Baldwin B. The relationship between college zoology students beliefs about evolutionary theory and religion. J Res Dev Educ. 1997;30:118-25.

Sproul B. Primal myths: creation myths from around the world. New York: HarperCollins; 1979.

Tidon R, Lewontin RC. Teaching evolutionary biology. Genet Mol Biol. 2004;27(1):124-31.

Winfield N. Vatican: Faithfull should listen to science. Associated Press 11/04. 2005. www.foxnews.com. Accessed 20 Feb 2009.

Zuzovsky R. Conceptualizing a teaching experience on the development of the idea of evolution: an epistemological approach to the education of science teachers. J Res Sci Teach. 1994;31(5):55774. 